\title{
GRAINS OF WHEAT
}

\section{Alesson learned.}

\section{BY ALEX SHVARTSMAN} the world's foremost pharmaceuticals company. Under his leadership, Green Industries had eradicated numerous ailments and made him the world's seventh-richest man in the process.

The genetic disease ravaging his body was so rare that it had never made financial sense to look for the cure. And by the time he'd learned that it afflicted him personally, it was far too late. His researchers worked feverishly, yet the breakthrough was months, perhaps years away. The doctors told him he had only a few days left.

"There is a woman asking to see you," said his assistant. "She's Rajan Jethwani's daughter."

All sorts of people sought an audience; bootlickers and sycophants, hoping to remind Bryce of their existence, in case there was somehow room for them in his will. $\mathrm{He}$ tolerated precious few visitors, and certainly not the child of a one-time business partner from decades ago.

He tried to wave his arm in dismissal, an IV drip and an array of sensor cables attached to it like marionette strings, but only managed to twitch a few fingers. Instead he whispered, "Send her away."

"She claims that a biotechnology start-up she runs in Bangalore has developed medicine that can treat your condition, sir."

A cure? No, it wasn't possible. This woman was playing some angle, telling him what he wanted to hear in order to gain access. Well played. He couldn't afford to refuse her.

"Hello, Uncle Bryce," said the Indian woman in her forties. "It's me, Rohana. You taught me to play chess when I was little, remember?"

Bryce recalled the annoyance of getting stuck watching his business partner's kid while Rajan spent evenings in the lab, so close to their firm's first breakthrough. Back then they couldn't afford a babysitter.

"We were just about to begin clinical trials on this drug when I heard of your diagnosis," she said. "Naturally, we did everything we could to accelerate the process." She held out a small pill. "This isn't a cure, but one of

\section{A \\ s she lay dying, Bryce Green contem- plated the irony of his predicament. He'd spent a lifetime building}
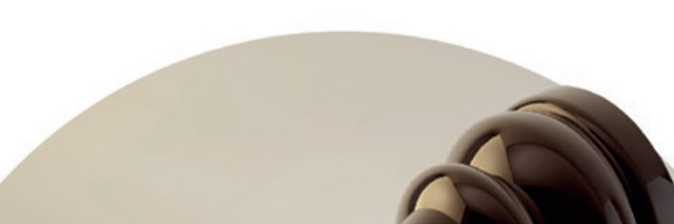
. taught me chess, you also told me a you about its creator. Do you remember it?"

Bryce shook his head.

"Some ancient king liked the game so much that he let the creator name his reward. The man wanted wheat: one grain for the first square of the chessboard, then double the amount for each subsequent square. The king agreed, not realizing the enormity of the request."

Rohana stared Bryce in the eye. "You told me that story around the time you 'forgot' to reapply for my father's work visa. He was forced to move back to India, and to sell you his share of the company mere months before you made millions off his research. He died in obscurity a decade ago, but you didn't even know that, did you?"

Bryce tried to say something, but Rohana cut him off.

these per day can alleviate your symptoms and prolong your life by a year or more."

Bryce was sceptical, but he had nothing to lose. With her help, he gulped down the pill.

Every day, Rohana Jethwani would visit and deliver another dose. She never stayed more than a few minutes or said much, but Bryce didn't care because the drug was working. He was getting stronger, feeling better than he had in weeks, beginning to eat solid food. On the seventh day she handed him a sheet of paper along with the pill.

"What's this?" Bryce asked. He was sitting up in bed, reading a quarterly report. He felt strong enough to work again.

"Your bill for the first week."

Aha! Bryce didn't believe in altruism and Rohana's kindness was making him somewhat uncomfortable. He'd gladly pay for treatment. He glanced at the bill and suppressed a chuckle; it was a measly $\$ 127$. Like her father, Rohana didn't seem to grasp that pharmaceuticals were always a sellers' market, and consumers would reach as deep as they had to into their pockets when it came
SNATURE.COM Follow Futures: @ @NatureFutures f go.nature.com/mtoodm to their well-being.
"Say, would you consider selling the formula? Or, perhaps, the entire company?"
"You need one pill per day to live, and I'm willing to supply them. Your first pill was a dollar, the second two dollars, and so forth. It's a pittance now, but your twenty-first pill will cost over a million, and it'll get really expensive after that. In the end, you'll either be dead or I'll own the company you stole from my father. And when I do, you and every other patient will receive care at rates they can afford."

"How dare you blackmail me!" Bryce crumpled the bill in his fist. "I will bring the full resources of Green Industries down on your foolish head."

“This isn't blackmail," said Rohana. "Just a business transaction. Business the way you'd handle it. Going forward, you will wire the money each day and a courier will deliver the pill. Your scientists won't be able to reverse-engineer the formula quickly enough, and if you try anything underhanded, the pills stop for good." She turned to leave. "The next time I see you, I'll either be in charge of Green Industries or attending your funeral. The choice is yours."

She walked away, Bryce still holding the bill in his shaking hand. .

Alex Shvartsman is a writer and game designer from Brooklyn, New York. Read more of his fiction at $w w w$. alexshvartsman.com. 